\title{
Variance Components for Test-Day Milk, Fat, and Protein Yield, and Somatic Cell Score for Analyzing Management Information
}

\author{
M. Caccamo, ${ }^{\star 1}$ R. F. Veerkamp,† G. de Jong,‡ M. H. Pool,† R. Petriglieri,, ${ }^{*}$ and G. Licitra* \\ ${ }^{*}$ Consorzio Ricerca Filiera Lattiero-Casearia (CoRFiLaC), Regione Siciliana, 97100 Ragusa, Italy \\ †Animal Breeding and Genomics Centre, Animal Sciences Group, PO Box 65, 8200 AB Lelystad, the Netherlands \\ †NRS, PO Box 454, 6800 AL Arnhem, the Netherlands
}

\section{ABSTRACT}

Test-day (TD) models are used in most countries to perform national genetic evaluations for dairy cattle. The TD models estimate lactation curves and their changes as well as variation in populations. Although potentially useful, little attention has been given to the application of TD models for management purposes. The potential of the TD model for management use depends on its ability to describe within- or between-herd variation that can be linked to specific management practices. The aim of this study was to estimate variance components for milk yield, milk component yields, and somatic cell score (SCS) of dairy cows in the Ragusa and Vicenza areas of Italy, such that the most relevant sources of variation can be identified for the development of management parameters. The available data set contained 1,080,637 TD records of 42,817 cows in 471 herds. Variance components were estimated with a multilactation, random-regression, TD animal model by using the software adopted by NRS for the Dutch national genetic evaluation. The model comprised 5 fixed effects [region $\times$ parity $\times$ days in milk (DIM), parity $\times$ year of calving $\times$ season of calving $\times$ DIM, parity $\times$ age at calving $\times$ year of calving, parity $\times$ calving interval $\times$ stage of pregnancy, and year of test $\times$ calendar week of test] and random herd $\times$ test date, regressions for herd lactation curve (HCUR), the animal additive genetic effect, and the permanent environmental effect by using fourth-order Legendre polynomials. The HCUR variances for milk and protein yields were highest around the time of peak yield (DIM 50 to 150), whereas for fat yield the HCUR variance was relatively constant throughout first lactation and decreased following the peak around 40 to 90 DIM for lactations 2 and 3. For SCS, the HCUR variances were relatively small compared with the genetic, permanent environmental, and residual variances. For

Received October 26, 2007.

Accepted April 2, 2008

${ }^{1}$ Corresponding author: caccamo@corfilac.it all the traits except SCS, the variance explained by random herd $\times$ test date was much smaller than the HCUR variance, which indicates that the development of management parameters should focus on betweenherd parameters during peak lactation for milk and milk components. For SCS, the within-herd variance was greater than the between-herd variance, suggesting that the focus should be on management parameters explaining variances at the cow level. The present study showed clear evidence for the benefits of using a random regression TD model for management decisions.

Key words: dairy cattle, herd management, testday yield

\section{INTRODUCTION}

Test-day (TD) yield records from the milk recording system provide an important source of information for both breeding and management. Herd management improvement and breeding value estimation have been separate processes historically, with different statistical methods and frequencies of data processing. However, there are clear advantages to using the same data and statistical procedures for both management purposes and genetic evaluation.

Test-day models are used in most countries to perform genetic evaluations for dairy cattle by using TD observations instead of aggregated 305-d yield observations (Ptak and Schaeffer, 1993; Reents et al., 1995; Jamrozik and Schaeffer, 1997a; Schaeffer et al., 2000). By modeling the shape of the lactation curve and the variability of yields around general shapes, TD models provide 4 to $8 \%$ more accurate genetic evaluations of cows compared with evaluations from 305-d yields (Schaeffer et al., 2000). Random regression TD models are an extension of TD models that allow the shape of the lactation curve to differ for each cow by including random regression coefficients for each animal (Schaeffer and Dekkers, 1994; Jamrozik et al., 1997b).

Everett et al. (1994) suggested using the results of TD models for monitoring genetics and management 
in dairy cattle, and several management applications have been suggested. Mayeres et al. (2004) and Pool and Meuwissen (1999) investigated the ability of a TD model to predict yield from TD records. The inclusion of herd-TD (HTD) and herd curve (HCUR) effects is another important aspect of TD models and would be applicable for management purposes. The HTD effect accounts for month-to-month variability and is particularly informative with regard to short-term management changes that affect the whole herd at a particular TD, for instance, a change in feed ration. Koivula et al. (2007) described the use of monthly herd-management effect solutions from a TD model in Finland. Herd curves, which can be calculated from the random regression TD model, describe differences in lactation curve shapes across herds (De Roos et al., 2004). Those herd-specific lactation curves give information on how animals within a herd perform compared with how they would have done under average management circumstances. Abnormalities in these curves can indicate specific existing problems that deserve extra attention. Variation in lactation peak or persistency across herds can be caused by differences in feeding systems (Horan et al., 2004), daily milking times (Rekik and Ben Gara, 2004), or pregnancy (Tekerli et al., 2000). Therefore, HCUR variance is a good indicator of variability in lactation curve shapes arising from herd management differences.

Given the many options in using the solutions or functions of the solutions of the TD model for interpreting herd management, an important first step is to identify the most important sources of within- and between-herd variation for the traits and population concerned. The second step is to develop management parameters that can link these sources of variation to differences in management practices. The objective of this study was to estimate variance components for TD milk, fat, and protein yield, and SCS by using a random regression TD model. Special focus is given to HCUR and HTD variances, which are mainly related to between- and within-herd management.

\section{MATERIALS AND METHODS}

\section{Data}

Test-day milk (kg), fat (g), and protein (g) yield, and SCC (cells $/ \mathrm{mL}$ ) records were available from 2 Italian regions: Ragusa in southeastern Sicily, and Vicenza in the south of Veneto. The records were supplied by CoRFiLaC (Ragusa, Italy) and APA Vicenza (Vicenza, Italy), respectively. In total, there were 4,088,505 TD records of 463,654 lactations of 154,678 cows in 1,303 herds over the period from January 1992 to March 2006. Values for SCC were transformed into SCS.
Data were edited to extract the more informative records and to ensure connectedness in the data, such as for continuous TD. Data were edited to select 1) records without missing values; 2 ) records with pedigree entry available, sire known, and a minimum of 9 daughters per sire; 3 ) records for 5 to 450 DIM; 4) age at calving in the range mean \pm 2 standard deviations; 5) records from HTD with at least 5 TD records; 6) herds with more than $10 \mathrm{HTD}$; 7) lactations with at least 5 TD records; and 8) lactations with a length of at least $150 \mathrm{~d}$. Data edits 2 through 8 were repeated iteratively until convergence (i.e., until the number of records deleted was negligible).

The resulting data included 2,183,322 TD records, $53 \%$ of the original. To reduce the memory requirements and computing time, the data set was further reduced by randomly deleting $50 \%$ of herds with animals belonging to the most common, larger breeds (Holstein-Friesian and Brown Swiss). To fulfill the above criteria, the editing procedure was repeated. The final data set used for parameter estimation contained 1,080,637 TD records from 118,580 lactations of 42,817 cows in 471 herds (Table 1 ).

Unknown parents were assigned to 145 phantom pedigree groups based on their selection path ( $\mathrm{SS}=$ sires to breed sons, SD = sires to breed daughters, $\mathrm{DS}=$ dams to breed sons, and DD = dams to breed daughters), breed, country of origin, and birth year. Small phantom groups were combined within selection path and birth year until reasonable size $(>200)$. The final pedigree was composed of $79.4 \%$ HolsteinFriesian and $15.1 \%$ Brown Swiss, with the remainder being small, crossbred, or unknown breeds.

\section{Model}

Milk, fat, and protein yield, and SCS were analyzed by using a multiple-lactation, single-trait random regression TD model, as described by De Roos et al. (2004):

$$
\begin{gathered}
\mathrm{y}_{\mathrm{ijklmnopst}}=\operatorname{rpd}_{\mathrm{i}}+\operatorname{pysd}_{\mathrm{j}}+\text { pay }_{\mathrm{k}}+\mathrm{pcipr}_{1}+\mathrm{yw}_{\mathrm{m}}+\mathrm{htd}_{\mathrm{n}} \\
+\sum_{\mathrm{q}=0}^{4} \mathrm{z}_{\mathrm{oq}}\left(\mathrm{hc}_{\mathrm{qs}}+\mathrm{ag}_{\mathrm{qst}}+\mathrm{pe}_{\mathrm{qst}}+\left\{\begin{array}{ll}
0, & \text { if } \mathrm{p}<3 \\
\mathrm{ls}_{\mathrm{pq}}, & \text { if } \mathrm{p} \geq 3
\end{array}\right\}\right) \\
+\mathrm{e}_{\mathrm{ijklmnopst}},
\end{gathered}
$$

where $\mathrm{y}_{\mathrm{ijklmnopst}}$ is yield record (milk, fat, or protein yield, or SCS) of cow t belonging to region $\mathrm{r}$ on DIM $\mathrm{d}$ of parity $p$ within HTD effect $n$; $\operatorname{rpd}_{i}$ is region $\times$ parity $\times$ class of DIM class $i\left(3,470\right.$ classes); pysd $_{j}$ is parity $\times$ year of calving $\times$ season of calving $\times$ class of DIM class $\mathrm{j}(1,656$ classes $)$; pay $_{\mathrm{k}}$ is parity $\times$ age at calving $\times$ year of calving class $\mathrm{k}$ (732 classes); pcipr $_{1}$ is parity $\times$ calving 
Table 1. Data characteristics of the data set before and after data editing and random selection of $50 \%$ of herds

\begin{tabular}{lrrc}
\hline Item & \multicolumn{1}{c}{ Before } & \multicolumn{1}{c}{ After } & Range \\
\hline Test-day records & $4,088,505$ & $1,080,637$ & - \\
Cows & 154,678 & 42,817 & - \\
Herds & 1,303 & 471 & - \\
Test days & 4,487 & 4,126 & - \\
Cows/herd & 120 & 91 & 10 to 999 \\
Test-day records/cow & 26 & 25 & 5 to 98 \\
Breeds & 11 & 7 & - \\
\hline
\end{tabular}

interval $\times$ stage of pregnancy class 1 ( 153 classes); $\mathrm{yw}_{\mathrm{m}}$ is year of test $\times$ calendar week of test class $\mathrm{m}(312$ classes); $h_{t d}$ is herd $\times$ test date $\mathrm{n}(49,053$ classes $)$; and $\mathrm{z}_{\mathrm{oq}}$ is order $\mathrm{q}$ Legendre polynomial for DIM $\mathrm{o}$ (Kirkpatrick et al., 1990), where o is $\min \{d, 365\}$. In this way TD records with DIM $>365$ were modeled as DIM = 365 with regard to the regression effects. $\mathrm{hc}_{\mathrm{qs}}$ is the herd curve effect of herd $\times$ year of test $(8,007$ classes) corresponding to polynomial $q$ of parity $\mathrm{s}$, where $\mathrm{s}$ is $\min \{\mathrm{p}, 3\}$. In this manner, each herd gets a regression curve for parity 1,2 , and $\geq 3 . \mathrm{ag}_{\mathrm{qst}}$ is the additive genetic effect of cow $t$ (59,882 classes) corresponding to polynomial q of parity s; pe $_{\mathrm{qst}}$ is the permanent environmental effect of cow $t(42,821$ classes $)$ corresponding to polynomial $q$ of parity $\mathrm{s}$; and $\mathrm{ls}_{\mathrm{pq}}$ is the lactation-specific permanent environmental effect of lactation $p$ corresponding to polynomial q (51,811 classes). Only TD records from lactations with parity $\geq 3$ are assigned to a lactation-specific permanent environmental effect. $\mathrm{e}_{\mathrm{ijklmnopst}}$ is the residual belonging to observation $\mathrm{y}_{\mathrm{ijkl}}$ mnopst.

Residuals were assumed to be uncorrelated between and within animals, with a heterogeneous variance across 27 DIM classes (15-d classes from DIM 5 to 365 , plus classes 366 to 390,391 to 420 , and 421 to 450 ) within parities $1,2,3,4$, and $\geq 5$. Fourth-order Legendre polynomials were applied to model the random and permanent environmental regression curves.

\section{Estimation Methods}

Parameters were estimated by using a Bayesian analysis with Gibbs sampling developed by NRS (De Roos et al., 2004). The algorithm was based on a GaussSeidel iterative BLUP scheme, as described by Janss and De Jong (1999) and was extended to the random regression model by Pool et al. (2000). Uniform priors were assumed for all variance components. Residual variances were sampled from an inverted chi-square distribution, whereas the covariance matrixes of the regression coefficients for the HTD, the additive genetic, the permanent environment, the HCUR, and the lactation-specific permanent environment effect were sampled from an inverted Wishart distribution. Burnin and effective chain length were computed from transition probabilities by using the Gibanal software (Van Kaam, 1998). Estimates of the variance components were calculated as posterior means of the stationary phase of the Gibbs chains.

\section{RESULTS}

\section{Gibbs Chains}

Based on the estimated burn-in for all chains and all parameters, a burn-in of 25,000 iterations was chosen for each chain and each parameter. Table 2 has the number of Gibbs chains, the total number of iterations in the chains, and the range in effective chain size across all parameters for milk, fat, protein, and SCS, with 50 being the minimum acceptable number for the effective chain size (Sorensen, 1997).

\section{TD Variance Components}

The estimated additive genetic, permanent environment, lactation-specific permanent environment, HTD, HCUR, and residual variances in lactations 1, 2 , and 3 for TD milk, fat, and protein yields, and SCS are given in Figures 1, 2, 3, and 4, respectively.

For all traits except SCS, additive genetic variances increased slowly during the lactation trajectory in all 3 parities. For milk and protein yields, the residual variance was relatively small compared with the total phenotypic variance, indicating a good fit of the model. The residual variance was larger for fat yield and largest for SCS, indicating that the model could explain less variance and that observations for these traits might therefore be less predictable.

Herd $\times$ test date variances for milk and milk components yields were much lower than HCUR variances, which indicates that differences between herds are larger than differences between test dates within a herd. Around peak yield (DIM 50 to 150), HCUR variances were greatest for milk and protein yield, whereas for SCS, HCUR variances were relatively small compared with the other variance components. This result indicates relatively small differences between herds for SCS.

In Figure 5, the estimated ratio of HCUR to phenotypic variances in lactations 1,2 , and 3 across DIM is shown for TD milk, fat, and protein yields, and SCS. For all traits except SCS, the ratio of HCUR to phenotypic variances peaked at around 50 to 150 DIM and decreased at the end of the lactation to approximately 0.15 , except for the first lactation, which did not decrease below 0.35 . The greatest HCUR over phenotypic variances were observed for protein yield. 
Table 2. Number of Gibbs chains, total number of iterations, and range of effective chain size for the variance component estimation of test-day milk, fat, and protein yields, and SCS

\begin{tabular}{lrrrrrrrr}
\hline Trait & \multicolumn{2}{c}{ Milk } & \multicolumn{2}{c}{ Fat } & \multicolumn{2}{c}{ Protein } & \multicolumn{2}{c}{ SCS } \\
\hline Chains, n & \multicolumn{2}{c}{3} & & 3 & & 3 & & 3 \\
Iterations, n (total) & \multicolumn{2}{c}{328,780} & 346,400 & 470,120 & 403,500 \\
Iterations, n (excluding burn-in) & \multicolumn{2}{c}{253,780} & 271,400 & & 395,120 & & 328,500 \\
Range in effective chain size & Min & Max & Min & Max & Min & Max & Min & Max \\
\hline Additive genetic & 203 & 510 & 206 & 554 & 314 & 653 & 240 & 609 \\
Permanent environment & 58 & 627 & 66 & 700 & 72 & 782 & 50 & 801 \\
Lactation-specific permanent environment & 938 & 10,940 & 449 & 16,341 & 1,111 & 15,652 & 709 & 13,441 \\
Herd curve & 455 & 1,819 & 310 & 2,645 & 445 & 3,674 & 253 & 2,797 \\
Herd $\times$ test date & 817 & 817 & 441 & 441 & 1,196 & 1,196 & 363 & 363 \\
Residual & 981 & 32,867 & 712 & 34,631 & 1,136 & 47,002 & 796 & 40,343 \\
\hline
\end{tabular}

Table 3 gives HCUR correlations among DIM 5, 65, 185,305 , and 365 for parities 1, 2, and 3. For all traits, HCUR correlations among DIM for parities 2 and 3 were similar, and both were higher than during parity 1. Overall correlations for all parities for milk, fat, and protein yields were high, ranging from 0.69 to 0.99 . On the other hand, correlations for SCS among DIM were low, with the lowest values for DIM 5 in the first parity.

Herd curves for second-parity protein yield for the 10 largest herds from Vicenza and the 10 largest herds from Ragusa are shown in Figure 6. It is surprising to see why there were such large differences in variation between the regions.

\section{DISCUSSION}

Variance components of TD milk, fat, and protein yields, and SCS were estimated by applying a random regression animal model to a large data set with records of dairy cows from the Ragusa and Vicenza areas of Italy. Estimated additive genetic, permanent environmental, and residual variances are in line with other studies (De Roos et al., 2004; Gengler et al., 2004).

The HCUR variances were highest around peak yield (DIM 50 to 150) for all traits except SCS. This is in contrast with the variances found by De Roos et al. (2004) and Gengler and Wiggans (2001). In that

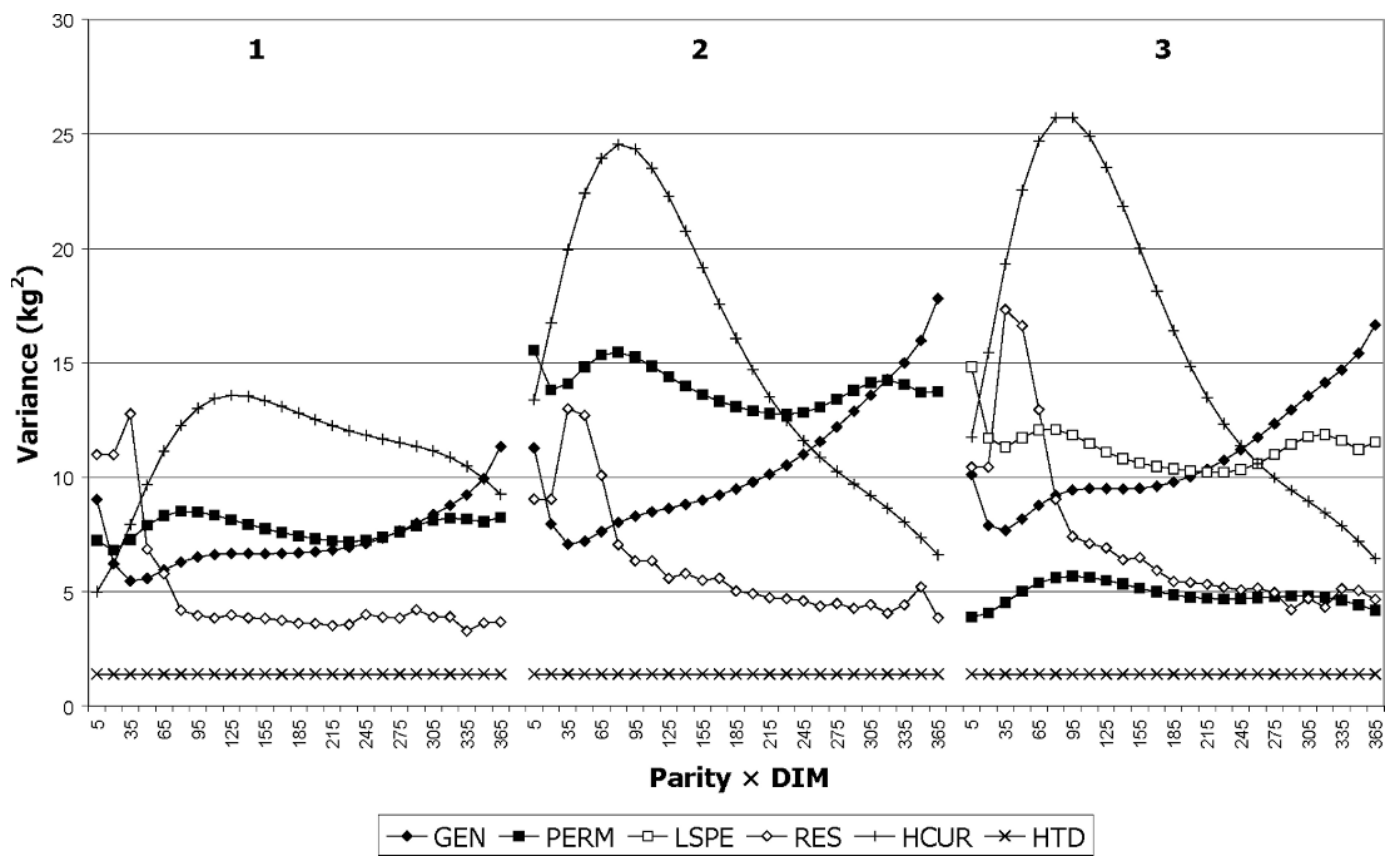

Figure 1. Additive genetic (GEN, $\diamond$ ), permanent environmental (PERM, $\mathbf{\square})$, lactation-specific permanent environmental (LSPE, $\square$ ), herd $\times$ test date $(\mathrm{HTD}, \times)$, herd curve $(\mathrm{HCUR},+)$, and residual $(\mathrm{RES}, \diamond)$ variance of test-day milk yield in lactations 1,2 , and 3 (in $\mathrm{kg}^{2}$ ). 


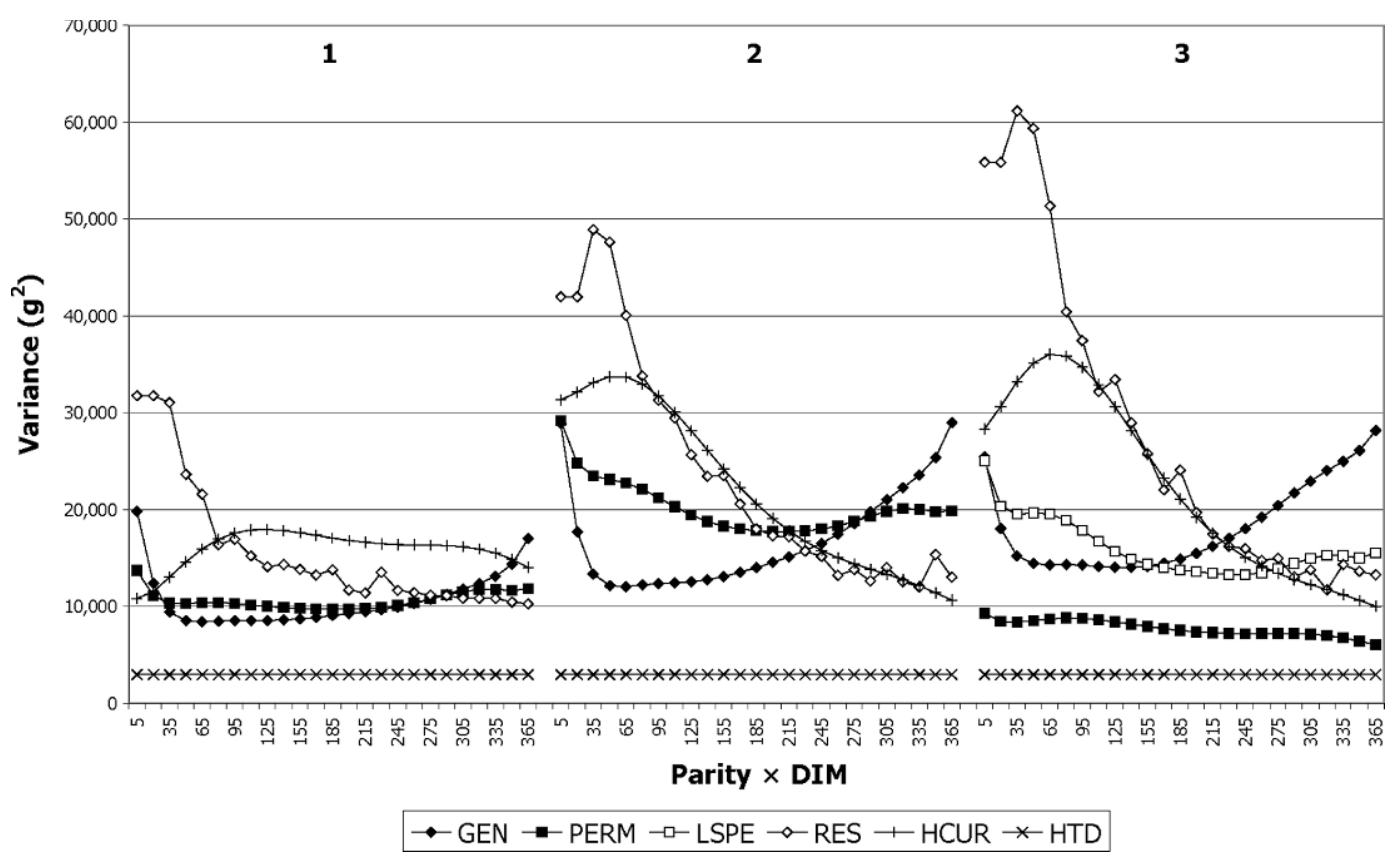

Figure 2. Additive genetic (GEN, $\bullet$ ), permanent environmental (PERM, $\square$ ), lactation-specific permanent environmental (LSPE, $\square$ ), herd $\times$ test date $(\mathrm{HTD}, \times)$, herd curve $(\mathrm{HCUR},+)$, and residual $(\mathrm{RES}, \diamond)$ variance of test-day fat yield in lactations 1,2 , and 3 (in $\mathrm{g}^{2}$ ).

study, variance of the random herd curves was greatest at the borders of the lactation and negligible in midlactation. This is surprising, and is probably an artifact of the missing data and the statistical model used to extrapolate the data (Pool and Meuwissen, 1999). Herd lactation curves are deviations from over-

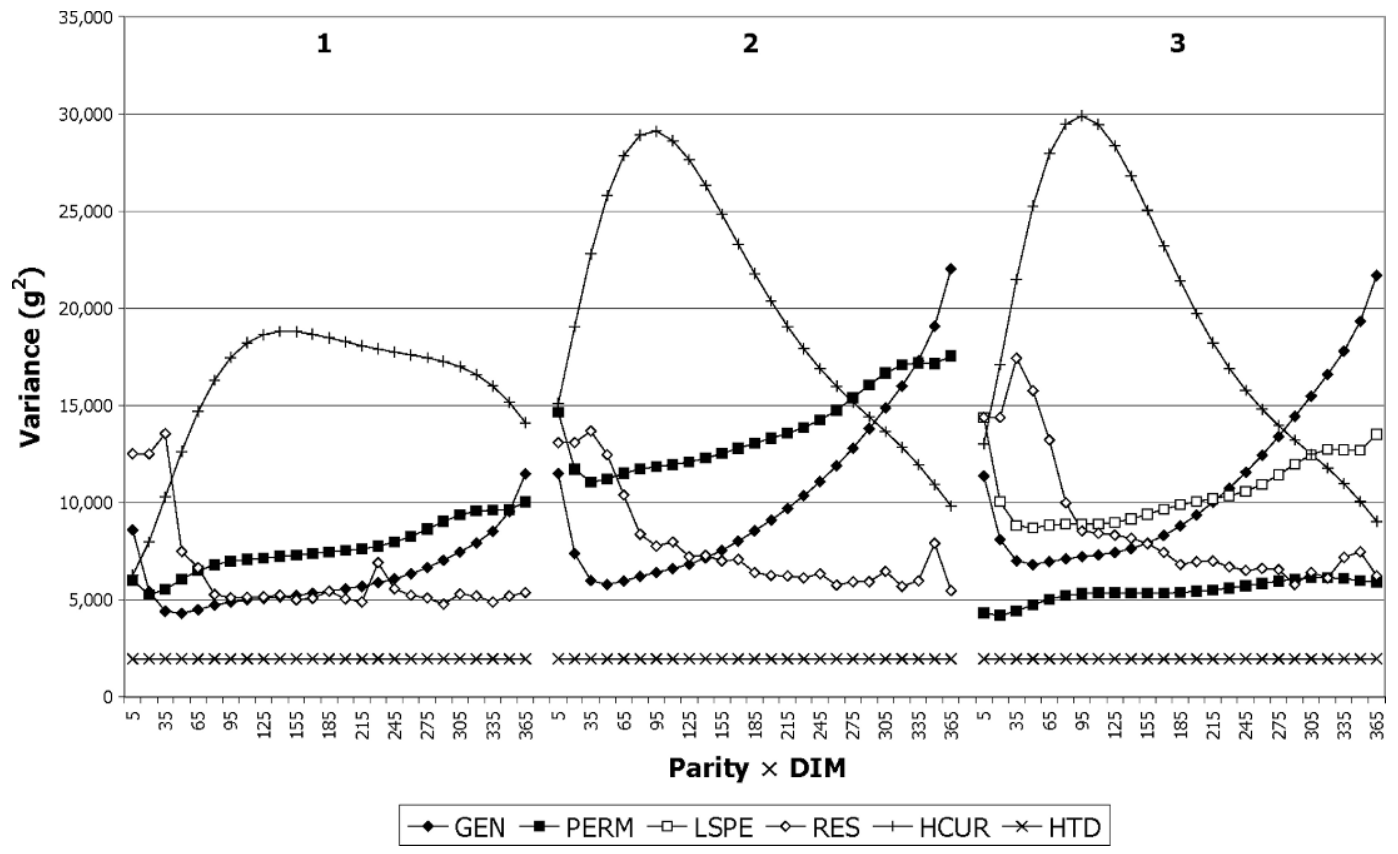

Figure 3. Additive genetic (GEN, $\diamond$ ), permanent environmental (PERM, $\mathbf{\square})$, lactation-specific permanent environmental (LSPE, $\square$ ), herd $\times$ test date $(\mathrm{HTD}, \times)$, herd curve $(\mathrm{HCUR},+)$, and residual $(\mathrm{RES}, \diamond)$ variance of test-day protein yield in lactations 1,2 , and 3 (in $\mathrm{g}^{2}$ ). 


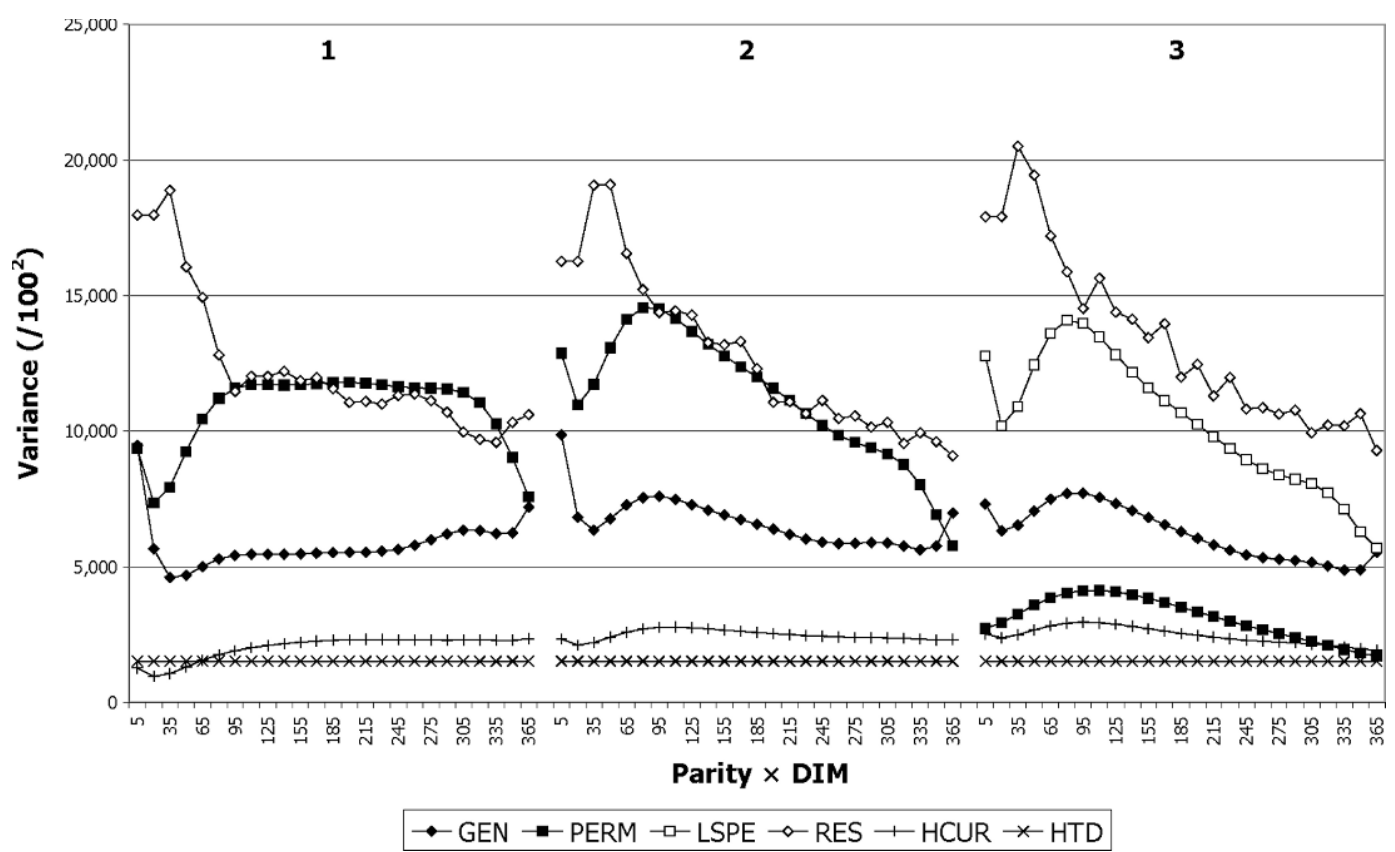

Figure 4. Additive genetic (GEN, $\diamond$ ), permanent environmental (PERM, $\square$ ), lactation-specific permanent environmental (LSPE, $\square$ ), herd $\times$ test date $(\mathrm{HTD}, \times)$, herd curve $(\mathrm{HCUR},+)$, and residual $(\mathrm{RES}, \diamond)$ variance of test-day SCS in lactations 1,2 , and 3 .

all curves and can be compared between herds. They indicate how the animals in the herd perform compared with how they would have done under average management circumstances. Greater variability at the peak indicates that differences in management between herds are expected to have the largest impact

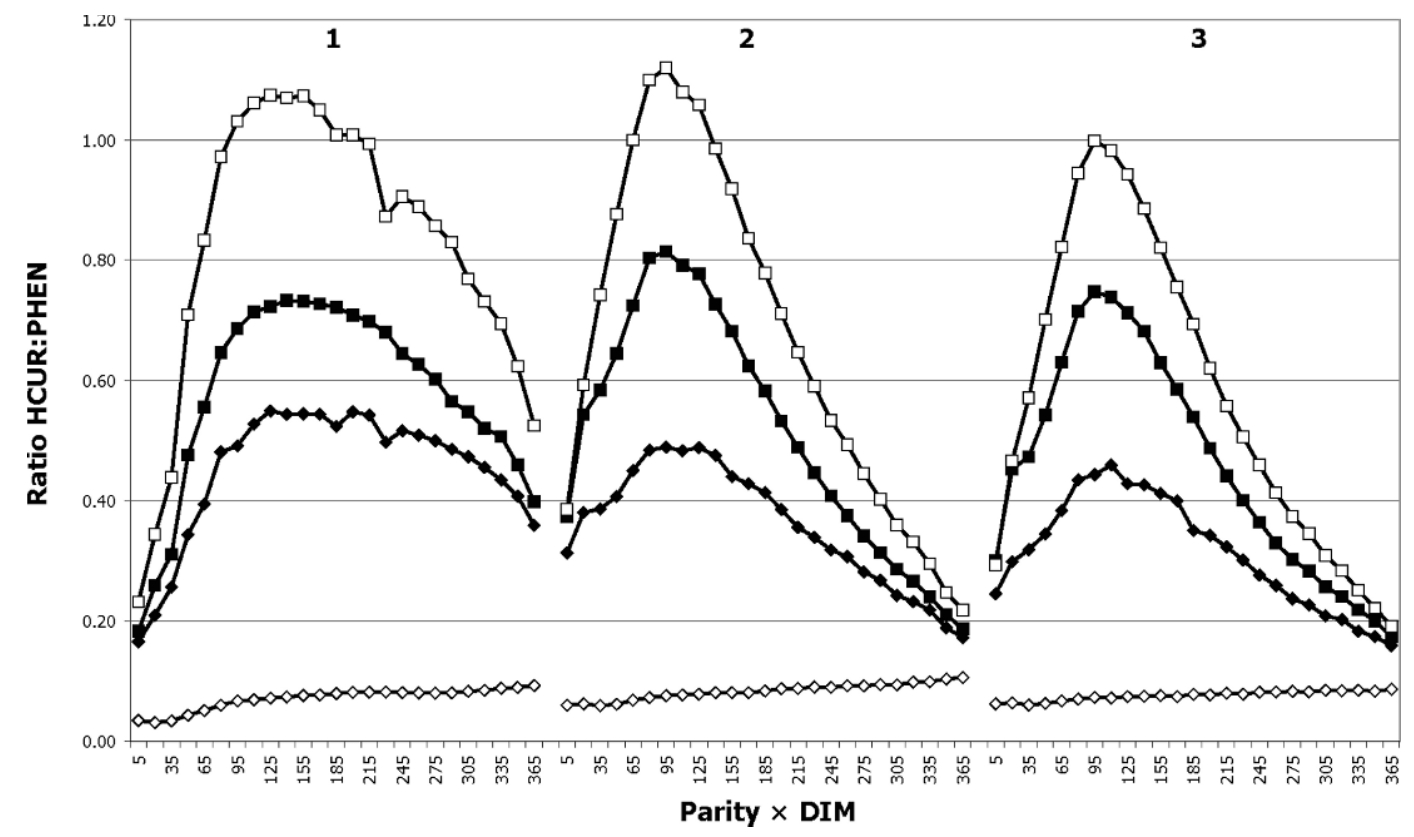

Figure 5. Ratio of the herd curve over phenotypic variance in lactations 1, 2, and 3 for test-day milk $(\square)$, fat $(\bullet)$, and protein ( $\square)$ yield, and SCS $(\diamond)$. 
Table 3. Correlations among DIM 5, 65, 185, 305, and 365 within parity 1, 2, and 3 from the random herd curve effect

\begin{tabular}{|c|c|c|c|c|c|c|c|c|c|c|c|c|c|}
\hline \multirow[b]{2}{*}{ Trait } & \multirow[b]{2}{*}{ DIM } & \multicolumn{4}{|c|}{ Lactation 1} & \multicolumn{4}{|c|}{ Lactation 2} & \multicolumn{4}{|c|}{ Lactation 3} \\
\hline & & DIM 65 & DIM 185 & DIM 305 & DIM 365 & DIM 65 & DIM 185 & DIM 305 & DIM 365 & DIM 65 & DIM 185 & DIM 305 & DIM 365 \\
\hline \multirow[t]{3}{*}{ Milk } & 5 & 0.78 & 0.71 & 0.69 & 0.69 & 0.92 & 0.90 & 0.88 & 0.85 & 0.87 & 0.85 & 0.85 & 0.84 \\
\hline & 185 & & & 0.99 & 0.97 & & & 0.98 & 0.91 & & & 0.98 & 0.93 \\
\hline & 305 & & & & 0.99 & & & & 0.96 & & & & 0.97 \\
\hline \multirow[t]{2}{*}{ Fat } & 5 & 0.81 & 0.71 & 0.67 & 0.65 & 0.92 & 0.87 & 0.82 & 0.78 & 0.90 & 0.86 & 0.82 & 0.81 \\
\hline & 65 & & 0.97 & 0.93 & 0.89 & & 0.98 & 0.92 & 0.85 & & 0.98 & 0.93 & 0.88 \\
\hline \multirow{4}{*}{ Protein } & 5 & 0.80 & 0.75 & 0.73 & 0.74 & 0.93 & 0.92 & 0.89 & 0.86 & 0.88 & 0.86 & 0.86 & 0.86 \\
\hline & 65 & & 0.98 & 0.96 & 0.94 & & 0.99 & 0.95 & 0.88 & & 0.99 & 0.96 & 0.91 \\
\hline & 185 & & & 0.99 & 0.98 & & & 0.98 & 0.92 & & & 0.98 & 0.94 \\
\hline & 305 & & & & 0.99 & & & & 0.97 & & & & 0.98 \\
\hline \multirow{3}{*}{ SCS } & 5 & 0.36 & 0.31 & 0.34 & 0.31 & 0.69 & 0.59 & 0.49 & 0.53 & 0.74 & 0.63 & 0.60 & 0.54 \\
\hline & 65 & & 0.84 & 0.86 & 0.80 & & 0.89 & 0.80 & 0.74 & & 0.92 & 0.89 & 0.81 \\
\hline & 185 & & & 0.96 & 0.95 & & & 0.94 & 0.90 & & & 0.96 & 0.92 \\
\hline
\end{tabular}

around the peak of the lactation. The ratio of HCUR over phenotypic variance can be interpreted as the ratio between across-herd and across-animal variation. This ratio was greatest for protein yield around the time of peak yield, with values greater than 1 for the first and second lactation, showing that variability between herds is greater than variability between animals. For this reason, it could be argued that development of management parameters for milk, fat, and protein yields around the peak should focus on be- tween-herd parameters rather than management parameters that compare individual cows. Therefore, greater HCUR variances represent a promising opportunity for management improvement between herds. As an example, positive herd curves for milk, fat, and protein and negative herd curves for SCS could indicate that herd management is better than average. Negative lactation herd curve traits (peak, mean, and persistency) are highly correlated with low-energy diets and low starch content in feeds. Because these

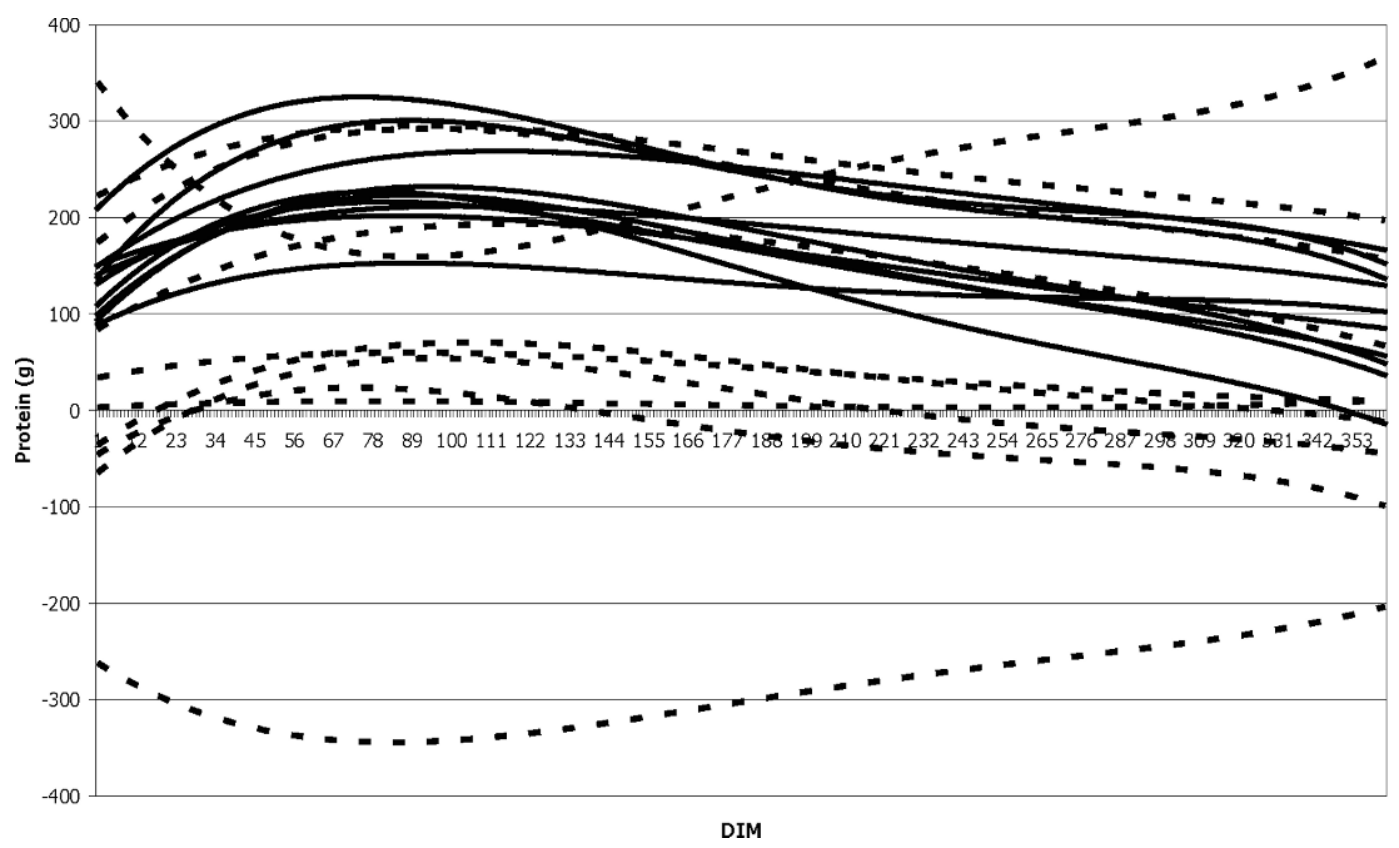

Figure 6. Herd curve for protein yield in second lactation of the 10 largest herds from Vicenza (-) and the 10 largest herds from Ragusa $(---)$. 
curves are estimated for successive years and are not primarily based on the most recent data, they indicate mid- to long-term management effects.

The HCUR variability is even more extreme if we compare HCUR vs. HTD variance, namely, betweenvs. within-herd variation. Herd-TD is defined as a deviation from the mean within each herd. Therefore, HTD estimates are not useful for comparing farms. The HTD effect is especially informative for immediate management changes that affect the whole herd at a precise TD. In particular, negative milk, fat, and protein deviations and positive SCS deviations indicate that cows produced less milk, fat, and protein and more cells than expected. A sudden drop in milk and fat content yield at a particular test day could alert managers of insufficient effective fiber in feeds that could lead to acidosis at the herd level. On the other hand, an increase in fat content combined with a drop in milk and protein yield could alert managers of an energy unbalance in the diets that could lead to ketosis. Positive SCS deviations could be due to malfunctions of the milking system or to infectious diseases. Higher variability in HCUR rather than an HTD effect would suggest that the focus should be on management parameters that describe between-herd variation; consequently, advice is needed mostly for long-term rather than short-term changes.

For SCS, both HCUR and HTD variances were relatively small compared with the other variance components. This would suggest that the focus should be on management parameters that describe betweenanimal variation; consequently, management considerations are needed mostly at the cow level for this trait. The HCUR correlations for SCS among DIM were also lower than for other traits and were very low between 5 and greater DIM, meaning that management practices affecting early lactation do not have a directly related impact on SCC later on in the same lactation.

The ratio of HCUR over phenotypic variance was highest for protein yield in the second lactation. The estimated herd curves of the 10 largest herds from Ragusa and the 10 largest herds from Vicenza for protein yield in the second lactation shown in Figure 6 clearly reveal much greater variation in the shape of the lactation curve as well as in the deviation from the lactation curve of the population for Ragusa than for Vicenza province. This greater variation is not simply caused by differences in the mean region effects that were included in the model as a fixed effect. A more likely option might be the lower and more variable feed quality in the Ragusa region, leading to more variation between herds. Further work will focus on identifying the sources of variation in these random herd curves across herds, including the measured feed quality at the herd level.

Test-day variance components estimated in the present study showed clear evidence of the benefits of using a random regression TD model for management improvement, by improving both between- and withinherd management aspects.

\section{ACKNOWLEDGMENTS}

The authors thank J. van Arendonk and. J. D. Ferguson for their scientific support. This research was funded in the "Accordo di Programma Quadro" action from the Assessorato Industria of the Sicilian Region (Palermo, Italy).

\section{REFERENCES}

De Roos, A. P. W., A. G. F. Harbers, and G. de Jong. 2004. Random herd curves in a test-day model for milk, fat, and protein production of dairy cattle in the Netherlands. J. Dairy Sci. 87:26932701.

Everett, R. W., F. Schmidt, and L. H. Wadell. 1994. A test-day model for monitoring management and genetics in dairy cattle. J. Dairy Sci. 77(Suppl. 1):267. (Abstr.)

Gengler, N., and G. R. Wiggans. 2001. Variance of effects of lactation stage within herd by herd yield. J. Dairy Sci. 84(Suppl. 1):216. (Abstr.)

Gengler, N., G. R. Wiggans, and A. Gillon. 2004. Estimated heterogeneity of phenotypic variance of test-day yield with a structural variance model. J. Dairy Sci. 87:1908-1916.

Horan, B., P. Dillon, D. P. Berry, P. O'Connor, and M. Rath. 2004. The effect of strain of Holstein-Friesian, feeding system and parity on lactation curves characteristics of spring-calving dairy cows. Livest. Prod. Sci. 95:231-241.

Jamrozik, J., and L. R. Schaeffer. 1997a. Estimates of genetic parameters for a test day model with random regressions for yield traits of first lactation Holsteins. J. Dairy Sci. 80:762-770.

Jamrozik, J., L. R. Schaeffer, and J. C. M. Dekkers. 1997b. Genetic evaluation of dairy cattle using test day yields and random regression model. J. Dairy Sci. 80:1217-1226.

Janss, L. L. G., and G. De Jong. 1999. MCMC based estimation of variance components in a very large dairy cattle data set. Pages 63-68 in Interbull Bull. No. 20. Interbull, Tuusula, Finland.

Kirkpatrick, M., D. Lofsvold, and M. Bulmer. 1990. Analysis of the inheritance, selection and evolution of growth trajectories. Genetics 124:979-993.

Koivula, M., J. I. Nousiainen, J. Nousiainen, and E. A. Mäntysaari. 2007. Use of herd solutions from a random regression test-day model for diagnostic dairy herd management. J. Dairy Sci. 90:2563-2568.

Mayeres, P., J. Stoll, J. Bormann, R. Reents, and N. Gengler. 2004. Prediction of daily milk, fat, and protein production by a random regression test-day model. J. Dairy Sci. 87:1925-1933.

Pool, M. H., L. L. G. Janss, and T. H. E. Meuwissen. 2000. Genetic parameters of Legendre polynomials for first parity lactation curves. J. Dairy Sci. 83:2640-2649.

Pool, M. H., and T. H. E. Meuwissen. 1999. Prediction of daily milk yields from a limited number of test days using test day models. J. Dairy Sci. 82:1555-1564.

Ptak, E., and L. R. Schaeffer. 1993. Use of test day yields for genetic evaluation of dairy sires and cows. Livest. Prod. Sci. 34:23-34.

Reents, R., J. C. M. Dekkers, and L. R. Schaeffer. 1995. Genetic evaluation for somatic cell score with a test day model for multiple lactations. J. Dairy Sci. 78:2858-2870. 
Rekik, B., and A. Ben Gara. 2004. Factors affecting the occurrence of atypical lactations for Holstein-Friesian cows. Livest. Prod. Sci. 87:245-250.

Schaeffer, L. R., and J. C. M. Dekkers. 1994. Random regressions in animal models for test-day production in dairy cattle. Page 443 in Proc. 5th World Congr. Genet. Appl. Livest. Prod., Guelph, Ontario, Canada.

Schaeffer, L. R., J. Jamrozik, G. J. Kistemaker, and B. J. Van Doormaal. 2000. Experience with a test-day model. J. Dairy Sci. 83:1135-1144.
Sorensen, D. 1997. Gibbs sampling in quantitative genetics. Internal Report No. 82. Danish Inst. Anim. Sci., Res. Ctr. Foulum, Tjele, Denmark.

Tekerli, M., Z. Akinci, I. Dogan, and A. Akcan. 2000. Factors affecting the shape of lactation curves of Holstein cows from the Balikesir province of Turkey. J. Dairy Sci. 83:1381-1386.

Van Kaam, J. B. C. H. M. 1998. Gibanal 2.9. Analyzing Program for Markov Chain Monte Carlo Sequences. Dept. Anim. Sci., Wageningen Agric. Univ., Wageningen, the Netherlands. 